\title{
Opieka pielęgniarska nad pacjentem z zespołem zależności alkoholowej
}

\author{
Nursing care for a patient with alcohol dependency \\ syndrome
}

MARIOLA RYBKA ${ }^{1}$, LIDIA JANKOWSKA ${ }^{2}$, JOANNA PRZYBYLSKA ${ }^{3}$

${ }^{1}$ Szpital Lipno Sp. Z o.o.

ORCID ID: https://orcid.org/0000-0003-1070-520X

${ }^{2}$ Wojewódzki Szpital Specjalistyczny im. Bł. Ks. J. Popiełuszki we Włocławku

${ }^{3}$ Państwowa Wyższa Szkoła Zawodowa we Włocławku, Instytut Nauk o Zdrowiu

DOI: http://dx.doi.org/10.21784//wP.2019.005

ISSN:2451-1846

\section{Streszczenie:}

Wstęp.Polska zajmuje czołowe miejsce w spożyciu alkoholu. Konsumpcja wykazuje tendencje wzrostową w porównaniu z początkiem lat $90 \mathrm{XX}$ wieku. Alkoholizm niesie ze sobą wiele problemów społecznych, psychologicznych oraz zdrowotnych. Jest chorobą, która może dotykać wiele osób nieświadomych swojego stanu.

Cel. Celem pracy jest przedstawienie na podstawie studium przypadku wybranych problemów występujących u osoby uzależnionej od alkoholu.

Opis przypadku. Pacjent lat 35. Przytomny $\mathrm{z}$ raną głowy, pamięta okoliczności zdarzenia, zgłasza bóle głowy, uporczywe drżenia oraz lęk. W wywiadzie od wielu lat uzależniony od alkoholu, wcześniej leczony psychiatrycznie z powodu zespołu abstynencyjnego w przebiegu choroby alkoholowej. zdezorientowany co do miejsca i czasu, przy zachowaniu własnej tożsamości, z nieco obniżonym nastrojem.

Dyskusja. Tematem dyskusji jest diagnostyka oraz etapy rozwoju choroby alkoholowej. Został również poruszony temat czynników środowiskowych prowadzących do uzależnienia 
Wnioski. 1. Nowoczesny wzorzec postępowania pielęgniarstwa psychiatrycznego realizowany jest $\mathrm{w}$ oparciu o zasady podmiotowego traktowania chorego poprzez uczestnictwo w procesie leczenia

2. Kluczową sprawą $w$ opiece nad pacjentem $\mathrm{z}$ ZZA jest właściwa komunikacja terapeutyczna, ukazanie autentyczności, otwartości, życzliwości oraz zrozumienia.

Słowa kluczowe: uzależnienie od alkoholu, opieka pielęgniarska, edukacja, abstynencja

\begin{abstract}
:
Introduction.Poland occupies a leading position in alcohol consumption. Consumption shows an upward trend compared to the beginning of the 1990. Alcoholism has many social, psychological and health consequences. It is a disease that can affect many people who are unaware of their condition.
\end{abstract}

Aim. The aim of the work is to present a case study of selected problems of a person addicted to alcohol.

A case report. Patient at the age of 35 , conscious, head injury he remembers the circumstances of the incident, reports headaches, persistent tremors and anxiety.Medical history shows long-term alcohol addiction, previously treated psychiatrically because of withdrawal syndrome in the course of alcoholism. Confused about the place and time, while maintaining his own identity, with a slightly lowered mood.

Discussion. The topic of discussion is diagnostics and stages of alkohol disease development. The topic of environment al factors leading to addiction Has also been addressed.

Conlusions. 1.The modern pattern of psychiatric nursing is based on the principles of patient treatment through participation in the treatment process. 2. The key issue in the care of the patient with mediastinum is proper therapeutic communication, showing the authenticity, openness, kindness and understanding.

Keywords: addiction to alcohol, nursing care, education, abstinence 


\section{Wstęp}

Alkoholizm niesie ze sobą wiele problemów społecznych, psychologicznych oraz zdrowotnych. Jest chorobą, która może dotykać wiele osób nieświadomych swojego stanu. Początki nałogu zazwyczaj wyglądają niewinnie i niestety bardzo ciężko określić cienką granice po przekroczeniu której, możemy być pewni, ze staliśmy się ofiarami uzależnienia alkoholowego. Alkoholizm to choroba, która dotyka zarówno osobę pijącą, jak i jej bliskich i ma zazwyczaj druzgocący wpływ na ich cale życie. Osoby z zespołem zależności alkoholowej często borykają się z problemami emocjonalnymi, które błędnie próbują zagłuszyć spożywaniem dużych ilości alkoholu [1].

Polska zajmuje czołowe miejsce w spożyciu alkoholu. Według danych Państwowej Agencji Rozwiązywania Problemów Alkoholowych w roku 2014 w Polsce spożycie $100 \%$ alkoholu wynosiło 9,4 litra na jednego obywatela. Dane statystyczne wskazują iż uzależnionych od alkoholu jest około $1 \mathrm{mln}$ osób, natomiast $6 \mathrm{mln}$ pije ryzykownie. Polacy gustują w alkoholach wysokoprocentowych, wypijają je w dużych ilościach i w krótkim czasie. Skutkiem tego jest częstość występowania zachowań agresywnych, przestępstw, chorób, urazów, wypadków samochodowych, przemocy w rodzinie, bezrobocia [2].Z badań przeprowadzonych na terenie Polski wynika, iż wiek inicjacji alkoholowej wynosi od 10-11 roku życia, a około 30-40\% młodzieży gimnazjalnej regularnie się upija. Alkohol nadużywa $12 \%$ dorosłych Polaków. Około $2 \%$ społeczeństwa to osoby uzależnione.

Uzależnienie od alkoholu jest wynikiem połączenia czynników genetycznych, psychologicznych, biologicznych i społecznych. Im więcej czynników ryzyka osoba ujawnia tym bardziej prawdopodobne jest, że stanie się alkoholikiem [2].

Dane Światowej Organizacji Zdrowia pokazują, że alkohol zajmuje trzecią pozycję pośród czynników ryzyka dla zdrowia 
ludności. Nadmierne używanie alkoholu toksycznie wpływa na narządy i układy organizmu. Złe odżywianie, co za tym idzie niedobory witamin i minerałów, spadek odporności, czyli skłonność do infekcji i zakażeń są przyczynami wystąpienia wielu zaburzeń somatycznych. Nadużywanie alkoholu prowadzi za sobą możliwość wystąpienia takich chorób jak: nadciśnienie tętnicze, udar krwotoczny mózgu, krwawienia śródczaszkowe, zaburzenia rytmu serca, najczęściej migotanie przedsionków, częstoskurcz komorowy, kardiomiopatia alkoholowa czyli przerost mięśnia sercowego. Ze strony układu pokarmowego najczęściej występują bóle brzucha, biegunki, krwawienia, refluks żołądkowo-przełykowy, zapalenie przełyku, żylaki przełyku, przewlekłe zapalenia żołądka i dwunastnicy, nieżyt jelita, zespół złego wchłaniania, zapalenie trzustki, stłuszczenie i marskość wątroby. Ponadto zaburzenia przemiany materiihiperglikemia, porfiria skórna, zaburzenia hormonalne, odwodnienie, hipokaliemia, niedobory witaminy B1 oraz magnezu [3].

Szkody spowodowane zażywanie środka psychotycznego w nadmiernych ilościach doprowadza do uszkodzenia obwodowego układu nerwowego. Przykładem tego jest polineuropatia alkoholowa zależna od długotrwałego spożywania środka, ma charakter postępujący. Objawia się pieczeniem dystalnych części kończyn górnych i dolnych, osłabieniem siły mięśniowej i odruchów głębokich.

Po dłuższym piciu może rozwinąć się halucynoza alkoholowa ujawnia się w ciągu 48 godzin po zaprzestaniu picia, początek jest nagły, natomiast majaczenia alkoholowe ujawniają się $\mathrm{w}$ ciągu 72 godzin od wypicia ostatniej dawki. Pojawia się lęk, problemy ze snem, urojenia, omamy, zaburzenia świadomości. Chory słyszy różne głosy, widzi chodzące po nim insekty, czuje się osaczony. Pojawia się podwyższona temperatura ciała oraz zaburzenia elektrolitowe. Efektem zmian w ośrodkowym układzie nerwowym jest ostry zespół amnestyczny zwany psychozą Wernickiego - Korsakowa. Objawia się problemami $\mathrm{z}$ pamięcią bieżącą a $\mathrm{z}$ zachowaniem wspomnień. Występują palimpsesty wypełnione konfabulacjami. Pacjent 
ma problemy z orientacją co do czasu, miejsca i przestrzeni. Następuje porażenie mięśni gałki ocznej, osłabienie siły mięśniowej, chód ataktyczny. Chory jest podekscytowany a jednocześnie apatyczny i nie może się skoncentrować. W późniejszym etapie choroby może ujawnić się obłęd opilczy zwany zespołem Otella. Choroba poprzedzona jest zazwyczaj bezpodstawnymi oskarżeniami wobec partnera życiowego o zdradę. Występuje chorobliwa zazdrość, snucie teorii spiskowych na temat niewierności i prześladowanie bliskiej osoby. Urojenia doprowadzają do przemocy fizycznej, a nawet do zbrodni [4].

W Polsce podstawę prawną rozwiązywania problemów alkoholowych stanowi Ustawa o wychowaniu w trzeźwości i przeciwdziałaniu alkoholizmowi z dnia 26 października 1992 roku. Leczenie odwykowe prowadzone jest $w$ zakładach leczniczych w rodzaju świadczeń stacjonarnych, całodobowych oraz ambulatoryjnych. Leczenie odwykowe jest dobrowolne, wyjątek stanowią „osoby, które w związku z nadużywaniem alkoholu powodują rozkład życia rodzinnego, demoralizację małoletnich, uchylają się od obowiązku zaspokajania potrzeb rodziny albo systematycznie zakłócają spokój lub porządek publiczny, kieruje się je na badanie przez biegłego w celu wydania opinii $\mathrm{w}$ przedmiocie uzależnienia od alkoholu i wskazania rodzaju zakładu leczniczego". Osoby uzależnione zgodnie z ustawą są objęte bezpłatnym leczeniem również w przypadku braku polisy ubezpieczeniowej $[4,5]$.

Celem pracy jest przybliżenie terminologii związanej $\mathrm{z}$ zespołem zależności alkoholowej, nakreślenie problematyki zjawiska zależności alkoholowej wśród społeczeństwa przedstawienie na podstawie studium przypadku wybranych problemów występujących u osoby uzależnionej od alkoholu.

Przedmiotem badań są działania pielęgniarki na rzecz podmiotu opieki, czyli pacjenta z Zespołem Zależności Alkoholowej.

\section{Prezentacja przypadku}


Pacjent lat 35. przywieziony przez karetkę pogotowia, skierowany $\mathrm{w}$ SOR jako powierzchowny uraz głowy. Mężczyzna przewrócił się na ulicy, przytomny, pamięta okoliczności zdarzenia, zgłasza bóle głowy. W SOR wykonano TK głowy bez kontrastu. Badanie bez zmian urazowych. Odbyła się konsultacja internistyczna z powodu osłabienia, niepokoju oraz bólu głowy i całego ciała. Pacjent zgłasza uporczywe drżenia. W wywiadzie od wielu lat uzależniony od alkoholu, pije ciągami wielomiesięcznymi. Podobne objawy miały już miejsce wcześniej, wówczas trafił do Szpitala Psychiatrycznego z rozpoznaniem zespołu abstynencyjnego $\mathrm{w}$ przebiegu choroby alkoholowej. Poddał się leczeniu odwykowemu, gdzie spędził półtora miesiąca. Utrzymywał abstynencje przez osiem miesięcy, jednakże ją przerwał. Ostatnio przez dwa tygodnie pił denaturat. Wystraszył się tego i od czterech dni nie pije alkoholu, zaczął widzieć węże, nie mógł spać, jeść, wystąpiły drżenia całego ciała. Chory wyraża chęć leczenia odwykowego jednak termin oczekiwania na ośrodek jest zbyt długi i pacjent nie radzi sobie $\mathrm{z}$ chorobą. $\mathrm{Z}$ powodu uzależnienia przyjmował leki ale nie pamięta nazw ani dawek. Twierdzi, że były one za mocne. W trakcie pobytu w SOR chory prezentował objawy lęku uogólnionego, które przejściowo dało się opanować przy użyciu leków. Zdezorientowany co do miejsca i czasu, przy zachowaniu własnej tożsamości, z nieco obniżonym nastrojem, z wyraźnym niepokojem o swoje zdrowie, zgłasza zaburzenia snu oraz apetytu. Zlecono pobranie krwi na badania, wykonanie prześwietlenia klatki piersiowej, usg jamy brzusznej. Po wynikach pacjent został skierowany do Szpitala Psychiatrycznego z zaburzeniami orientacji co do czasu i miejsca, ale zachowanej co do własnej tożsamości, z występującymi drżeniami całego ciała, obniżonym nastrojem oraz lękiem uogólnionym. Pacjent ma omamy wzrokowe, zaburzenia snu oraz łaknienia. Od dwóch dni zaobserwował luźne stolce. Jest spocony, temperatura jego ciała to $37^{\circ} \mathrm{C}$. Pozostałe parametry przy przyjęciu wynosiły kolejno: tętno 100/min, niemiarowe, oddech 20/min, ciśnienie 140/90 mmHg. Pacjent jest kawalerem, mieszka z rodzicami. Stracił prace z powodu 
nałogu, utrzymuje się z prac dorywczych. Chory zaniepokojony swym stanem zdrowia wyraża zgodę na podjęcie leczenia.

W tabeli 1 przedstawiono dane dotyczące pacjenta zebrane $\mathrm{w}$ ramach badania podmiotowego i przedmiotowego.

Tabela 1. Dane o pacjencie .

\begin{tabular}{|c|c|}
\hline \multicolumn{2}{|l|}{ Imię i nazwisko (inicjały): W.D. } \\
\hline Data urodzenia: $09.12 .1982 \mathrm{r}$. & \multirow{2}{*}{$\begin{array}{l}\text { Stan cywilny: kawaler } \\
\text { Wykonywany zawód: murarz }\end{array}$} \\
\hline Aktywność zawodowa: nie & \\
\hline \multicolumn{2}{|l|}{ Data zbierania wywiadu: $05.02 .2018 \mathrm{r}$. } \\
\hline HISTORIA CHOROBY & STAN OGÓLNY - średni \\
\hline $\begin{array}{l}\text { Rozpoznanie lekarskie: Lęk uogólniony, } \\
\text { majaczenie alkoholowe }\end{array}$ & Temperatura: $37^{\circ} \mathrm{C}$ \\
\hline $\begin{array}{l}\text { Przyjmowane leki: Diazepamam, Haloperidol, } \\
\text { Chlorprothixen, Coaxil, Wit. B1, 0,9\% Na Cl, PWE, } \\
\text { 5\% Glukoza, Espumisan, Captopril }\end{array}$ & \begin{tabular}{|l} 
Tętno \\
(liczba/napięcie/rytm): \\
100 uderzenia na \\
min./dobrze \\
napięte/niemiarowe
\end{tabular} \\
\hline Przebyte choroby: ---- & $\begin{array}{l}\text { Oddechy: } \\
\text { oddechów/min. }\end{array}$ \\
\hline Pobyty w szpitalu: kolejny & $\begin{array}{l}\text { Ciśnienie } \\
\text { 140/90mmhg }\end{array}$ \\
\hline Przebyte zabiegi operacyjne: ---- & Masa ciała: $58 \mathrm{~kg}$ \\
\hline \multirow{3}{*}{$\begin{array}{l}\text { Przebyte urazy/wypadki: powierzchowny uraz } \\
\text { głowy }\end{array}$} & Wzrost: $177 \mathrm{~cm}$ \\
\hline & \begin{tabular}{|l} 
BMI: $\quad 18,51$-granica \\
prawidłowego wyniku
\end{tabular} \\
\hline & $\begin{array}{l}\text { WHR: } \\
\text { prawidłowy }\end{array}$ \\
\hline
\end{tabular}


Członkowie rodziny: rodzice

Ważne wydarzenia $w$ rodzinie - ostatnie lata: ślub brata

Choroby występujące $w$ rodzinie: cukrzyca

Hobby/zainteresowania: motoryzacja

Formy spędzania wolnego czasu: oglądanie telewizji

Nałogi w rodzinie: brak

Błędy żywieniowe - jakościowe i ilościowe: spożywanie posiłków o nieregularnych porach;

Ograniczenia/przeciq̨żenia psychicznego/fizyczne: utrata pracy, niepokój, drżenia ciała

Ograniczone kontakty/brak wsparcia społecznego: ograniczony kontakt z bratem z powodu nadużywania alkoholu

\section{WYWIAD ŚRODOWISKOWY}

Miejsce zamieszkania (miasto/wieś): wieś

Rodzaj zajmowanego lokalu mieszkalnego: wolnostojacy dom jednorodzinny

Ilość zajmowanych pomieszczeń: 4

Ilość osób mieszkających wspólnie: 3

Stan higieniczno-sanitarny mieszkania: dobry

System pracy: bezrobotny

Ilość godzin spędzonych $w$ pracy/szkole: prace dorywcze

Zagrożenia zdrowia: $w$ domu/w pracy/szkole:

Komunikacja: zaburzona

Higiena osobista: dość dobra

Aktywność fizyczna: pełna

Wydalanie: zaburzone, występujq luźne stolce, co jest wynikiem nadużywania alkoholu

Odżywianie: brak łaknienia

Sen/zasypianie: zaburzony

W tabeli 2 zaprezentowano proces pielęgnowania pacjenta przyjętego do oddziału psychiatrycznego. W planowaniu interwencji pielęgniarskich wykorzystano terminy zaczerpnięte $z \quad I C N P \circledast$ (Międzynarodowej Klasyfikacji Praktyki Pielęgniarskiej) - wersja 2017 r. 


\begin{tabular}{|c|c|c|}
\hline $\begin{array}{l}\text { Diagnoza } \\
\text { ICNP® }\end{array}$ & Interwencje ICNP & Diagnoza INCP® \\
\hline $\begin{array}{l}\text { Uzależnienie od } \\
\text { alkoholu } \\
{[10041347]}\end{array}$ & $\begin{array}{ll}\text { - } & \text { ciaggły nadzór } \\
& {[10005093],} \\
\text { - } & \text { monitorowanie zespołu } \\
& \text { abstynencyjnego } \\
& {[10036343]} \\
\text { - } & \text { nauczanie o } \\
& \text { nadużywaniu alkoholu } \\
& \text { [10044900], } \\
\text { - } & \text { promowanie wsparcia } \\
& \text { społecznego } \\
& \text { [10024464], } \\
\text { - } & \text { zapewnienie wsparcia } \\
& \text { emocjonalnego } \\
& \text { [10027051], } \\
\text { - } & \text { zachęcanie do } \\
\text { odpoczynku } \\
\text { - } \text { terapia odwracająca } \\
\text { uwagę [10039348], } \\
\text { - wzmacnianie osiągnięć } \\
\text { [10026427], } \\
\text { promowanie poczucia } \\
\text { własnej wartości } \\
\text { [10024455]. }\end{array}$ & $\begin{array}{l}\text { Bez nadużywania } \\
\text { alkoholu } \\
{[10028765],}\end{array}$ \\
\hline $\begin{array}{l}\text { Splątanie } \\
\text { [10023633] }\end{array}$ & $\begin{array}{ll}\text { - } & \text { ocenianie funkcji } \\
& \text { poznawczych } \\
& {[10025883],} \\
\text { - } & \text { monitorowanie } \\
& \text { splątania [10045424], } \\
\text { - } & \text { poradnictwo dotyczące }\end{array}$ & $\begin{array}{l}\text { Zmniejszone } \\
\text { splątanie } \\
{[10027098]}\end{array}$ \\
\hline
\end{tabular}




\begin{tabular}{|c|c|c|}
\hline & $\begin{array}{ll} & \text { strachu[10026208], } \\
\text { - } & \text { nauczanie o technikach } \\
\text { adaptacyjnych } \\
\text { [10023717], } \\
\text { - } \text { trening orientacji w } \\
\text { rzeczywistości } \\
\text { [10041072], } \\
\text { - zapewnienie ciągłości } \\
\text { opieki [10006966], } \\
\text { - zapewnienie wsparcia } \\
\text { emocjonalnego } \\
\text { [10027051], } \\
\text { - ewaluacja } \\
\text { psychospołecznej } \\
\text { odpowiedzi na plan } \\
\text { opieki [10007153]. }\end{array}$ & \\
\hline $\begin{array}{l}\text { Halucynacje } \\
\text { [10022500] }\end{array}$ & $\begin{array}{l}\text { - } \text { zarządzanie } \\
\text { halucynacjami } \\
\text { [10035818], } \\
\text { • ocenianie możliwości } \\
\text { [10026040]. } \\
\text { - obserwacja zmienionej } \\
\text { percepcji [10013517], } \\
\text { - nauczanie o } \\
\text { bezpieczeństwie w } \\
\text { środowisku [10044937]. }\end{array}$ & $\begin{array}{l}\text { Efektywna } \\
\text { percepcja } \\
\text { sensoryczna } \\
{[10028173]}\end{array}$ \\
\hline $\begin{array}{ll}\text { Zaburzony sen } \\
{[10027226]}\end{array}$ & $\begin{array}{ll}\text { - } & \text { ocenianie zmęczenia } \\
& {[10026086]} \\
\text { - } & \text { demonstrowanie technik } \\
\text { relaksacyjnych } \\
\text { [10024365], } \\
\text { - zachęcanie do }\end{array}$ & $\begin{array}{ll}\text { Adekwatny } & \text { sen } \\
{[10024930]} & \end{array}$ \\
\hline
\end{tabular}




\begin{tabular}{|c|c|c|}
\hline & $\begin{array}{l}\text { odpoczynku } \\
{[10041415]} \\
\text { - ocenianie } \\
\text { przestrzegania diety } \\
{[10044481],} \\
\text { - administrowanie lekiem } \\
\\
{[10025444]}\end{array}$ & \\
\hline $\begin{array}{l}\text { Brak równowagi } \\
\text { elektrolitowej } \\
{[10033541]}\end{array}$ & \begin{tabular}{|l}
$\bullet$ ocenianie zachowań \\
związanych z jedzeniem i \\
piciem [10002747], \\
$\bullet$ monitorowanie status \\
fizjologicznego \\
[10012183], \\
• podawanie płynów \\
[10039330] \\
• współdziałanie w terapii \\
elektrolitami [10030948], \\
• współdziałanie w terapii \\
płynami [10030948], \\
- ewaluacja odpowiedzina \\
terapię płynami \\
[10007176],
\end{tabular} & $\begin{array}{l}\text { Efektywna } \\
\text { równowaga } \\
\text { elektrolitowa } \\
\text { [10033709] }\end{array}$ \\
\hline $\begin{array}{l}\text { Brak apetytu } \\
{[10033399]}\end{array}$ & $\begin{array}{l}\bullet \text { nauczanie o odżywianiu } \\
\text { [10024618], } \\
\bullet \text { nauczanie o przyjmowaniu } \\
\text { jedzenia [10032939], } \\
\text { • zachęcanie [10006823], } \\
\text { • ocenianie zdolności do } \\
\text { przygotowania pokarmu } \\
\text { [10030536], } \\
\text { • ocenianie postawy wobec }\end{array}$ & $\begin{array}{l}\text { Pozytywny apetyt } \\
{[10040333]}\end{array}$ \\
\hline
\end{tabular}




\begin{tabular}{|c|c|c|}
\hline & \begin{tabular}{|l} 
status odżywienia \\
[10002694, \\
$\bullet$ współdziałanie przy \\
reżimie diety [10026190], \\
$\bullet$ podawanie leku \\
[10040708], \\
• ewaluacja odpowiedzi na \\
lek [10007182], \\
- ewaluacja status przewodu \\
pokarmowego \\
[10034007].
\end{tabular} & \\
\hline $\begin{array}{l}\text { Biegunka } \\
{[10000630]}\end{array}$ & \begin{tabular}{|l} 
- zarządzanie \\
wypróżnieniem \\
[10041427], \\
• współdziałanie w terapii \\
płynami [10033093], \\
• współdziałanie w terapii \\
elektrolitami [10030948], \\
- monitorowanie \\
odpowiedzi na leczenie \\
[10032109], \\
$\bullet$ nauczanie o reżimie diety \\
[10026525], \\
$\bullet$ monitorowanie masy ciała \\
[10032121], \\
$\bullet$ ewaluacja status przewodu \\
pokarmowego \\
[10034007], \\
$\bullet$ ewaluacja odpowiedzi na \\
lek [10007182]
\end{tabular} & $\begin{array}{l}\text { Bez biegunki } \\
{[10040063]}\end{array}$ \\
\hline
\end{tabular}




\begin{tabular}{|c|c|c|}
\hline $\begin{array}{l}\text { Brak wiedzy o } \\
\text { procesie zmiany } \\
\text { zachowań } \\
{[10024734]}\end{array}$ & $\begin{array}{l}\text { • ocenianiegotowości do } \\
\text { uczeniasię [10002781], } \\
\text { - nauczanie o leku/leczeniu } \\
\text { [10019470], } \\
\text { • nauczanie o reżimie } \\
\text { terapeutycznym } \\
\text { [10024625], } \\
\text { - ocenianie reakcji } \\
\text { nanauczanie [10024279], } \\
\text { - dostarczenie usług } \\
\text { promocji zdrowia } \\
\text { [10032522], } \\
\text { • zapewnienie materiału } \\
\text { instruktażowego } \\
\text { [10024493], } \\
\text { • ocenianie radzenia sobie } \\
\text { [10002723] } \\
\text { • ułatwienie do leczenia } \\
\text { [10024401], } \\
\text { • wzmacnianie osiągnięć } \\
\text { [10026427], } \\
\text { • wspieranie status } \\
\text { psychologicznego } \\
\text { społecznego [10024464] } \\
\text { granic [10019161], } \\
\text { własnej wartości } \\
\text { [10024455], } \\
\text { - promowanie ustanawiania }\end{array}$ & $\begin{array}{l}\text { Wiedza o procesie } \\
\text { zmiany zachowań } \\
{[10024723]}\end{array}$ \\
\hline
\end{tabular}




\begin{tabular}{|c|c|c|}
\hline & \begin{tabular}{|l} 
• wzmacnianie \\
samoskuteczności \\
[10022537], \\
• uzgadnianie \\
przestrzegania zaleceń \\
[10024349]
\end{tabular} & \\
\hline $\begin{array}{l}\text { Brak wsparcia } \\
\text { rodziny } \\
{[10022473]}\end{array}$ & \begin{tabular}{|l}
$\bullet$ ocenianie gotowości do \\
uczenia się [10002781], \\
$\bullet$ nauczanie rodziny o \\
chorobie [10021719], \\
$\bullet$ nauczanie rodziny o \\
delirium [10026518], \\
$\bullet$ raportowanie status \\
członkowi rodziny \\
[10016825], \\
$\bullet$ skrining nadużywania \\
alkoholu [10045476], \\
$\bullet$ nauczanie rodziny o \\
reżimie terapii \\
[10024656], \\
$\bullet$ ocenianie reakcji na \\
nauczanie [10024279], \\
$\bullet$ dostarczenie usług \\
promocji zdrowia \\
[10032522], \\
$\bullet$ ustalanie relacji \\
[10023738], \\
$\bullet$ wspieranie rodziny w \\
procesie podejmowania \\
decyzji [10026462], \\
$\bullet$ ułatwienie możliwości
\end{tabular} & $\begin{array}{l}\text { Pozytywne } \\
\text { wsparcie rodziny } \\
{[10045702]}\end{array}$ \\
\hline
\end{tabular}




\begin{tabular}{|l|l|l|}
\hline & $\begin{array}{l}\text { wykonywania roli } \\
{[10026277],} \\
\text { zapewnienie wsparcia } \\
\text { społecznego [10027046], }\end{array}$ & \\
\hline
\end{tabular}

Źródło: wynik badań własnych

\section{Wskazówki pielęgniarskie dla pacjenta}

Osoba uzależniona chcąc podjąć walkę z chorobą alkoholową musi uświadomić sobie jak poważne jest to schorzenie, wykazać się dobrymi chęciami i ogromnym uporem w dążeniu do celu. Stosując się do pewnych zasad i wskazówek zespołu terapeutycznego utrzyma życie w trzeźwości.

- poinformowanie chorego o dalszym leczeniu w Poradni Zdrowia Psychicznego odwyku, zażywaniu zleconych leków przez lekarza, uczestnictwie $w$ psychoterapii indywidualnej i grupowej, zachęcenie do udziału w zajęciach edukacyjnych na temat choroby, treningach interpersonalnych, na których pacjent uczy się funkcjonowania w środowisku, sesjach prewencji nawrotom nałogu, mitingach AA,

- bezwzględny zakaz picia alkoholu: unikanie osób, sytuacji, miejsc, w których można spożyć alkohol bądź takie, które będą się kojarzyły z chęcią wypicia. Nauczyć się odmawiać konsumpcji alkoholu. Pozbycie się z domu trunku również bezalkoholowego oraz produktów, które mogą wyzwalać głód alkoholowy na przykład słodycze, kosmetyki,

- niedopuszczenie do tego by negatywne emocje były pretekstem do wypicia trunku, zadbać o prawidłowy sen, spotykać się z przyjaznymi ludźmi, unikać przepracowania, planować dzień i zakupy, przestrzegać prawa, zasad społecznych, nie użalać się nad sobą, 
- prawidłowe odżywianie się, dostarczenie energii i składników odżywczych, dieta dostosowana do rzeczywistego stanu zdrowia pacjenta, niskoprzetworzona, pełnowartościowa, bogata w witaminy A, C, E, D, witaminy z grupy B, mikroelementy: Ca, Fe, $\mathrm{Zn}, \mathrm{Mg}, \mathrm{Sn}$,

- aktywność fizyczna dostosowana do stanu zdrowotnego oraz wydolność pacjenta: spacery, gimnastyka $\mathrm{w}$ basenie, stosowanie technik radzenia sobie $\mathrm{z}$ głodem alkoholowym: relaksacja, ćwiczenia oddechowe, planowanie aktywności.

\section{Wskazówki pielęgniarskie dla rodziny}

- nie zawierzać alkoholikowi, że sam poradzi sobie z nałogiem,

- nie przynosić do domu alkoholu,

- podtrzymywać na duchu, wspierać podczas pozytywnych skutków terapii,

- nie dodawać otuchy pijącemu alkoholikowi, niech zderzy się z przykrą rzeczywistością, poniesie konsekwencje,

- nie brać do siebie tego co mówi osoba uzależniona w trakcie picia, przemawia przez nią alkohol, nie pozwolić by dominował, narzucał swe zdanie,

- ważne sprawy poruszać tylko z trzeźwym alkoholikiem.

\section{Dyskusja}

Uzależnienie od alkoholu jest wynikiem połączenia czynników genetycznych, psychologicznych, biologicznych i społecznych. Im więcej czynników ryzyka osoba ujawnia tym bardziej prawdopodobne jest, że stanie się alkoholikiem.

Cierpiałkowska L. wyszczególnia 2 typy alkoholizmu[4]:

- typ 1 uwarunkowany środowiskowo: początek choroby występuje po 25 roku życia, nie jest związany z problemem alkoholizmu 
w rodzinie. Osoby te piją okresowo $\mathrm{z}$ długimi przerwami trzeźwości. Dochodzi tu do powikłań takich jak choroby majaczenie drżenne, choroby somatyczne,

- typ 2 uwarunkowany genetycznie: pojawia się częściej u mężczyzn niż kobiet, osoby te piją często, bez dłuższych przerw, nie występują u nich żadne powikłania psychiczne i somatyczne [5].

Za sprawą szybko rozwijającego się w latach $30 \mathrm{w}$ Stanach Zjednoczonych ruchu anonimowych alkoholików zaczęto postrzegać alkoholizm jako chorobę przewlekłą prowadząco do śmierci. Takie przedstawienie sprawy wymusiło na wielu naukowcach, psychologach, lekarzach przyjęcia odpowiedniego stanowiska. Brakowało jednak badań klinicznych, które potwierdziłyby tę tezę. W 1952 roku Jellinek postanowił przeprowadzić specjalistyczne badania kliniczne określające przebieg i symptomy alkoholizmu [4].Po przeanalizowaniu historii chorób alkoholików przedstawił schemat i przebieg alkoholizmu według następujących faz:

Faza wstępna - nadużywanie alkoholu w tej fazie motywowane jest społecznie, jednak w odróżnieniu od innych osób pijących w celach towarzyskich, przyszły alkoholik zaczyna odczuwać ulgę psychiczną, odprężenie i satysfakcje z zaistniałego stanu upojenia alkoholowego. Picie dużej ilości alkoholu staje się dla niego sposobem na uśmierzenie bolesnych stanów emocjonalnych, zatem ulga odczuwalna jest silniej niż u innych osób zażywających alkohol. Początkowo stosowany okazjonalnie z czasem staje się lekiem na wszelkie sytuacje stresowe, co prowadzi do codziennego picia. Zaczyna wzrastać tolerancja na alkohol, a przyszły alkoholik zmuszony jest na zwiększenie zażywanych dawek, by mogły one przynieść takie same skutki jak na początku. Pojawiają się pierwsze amnezje spowodowane nadużywaniem alkoholu.

Faza zwiastunów (ostrzegawcza) -według Jellinka zaczyna się na ogół od nagłego pojawienia się palimpsestów alkoholowych wskutek przyjęcia dużych dawek alkoholu, potem przewijają się coraz częściej. 
Dodatkowo w fazie tej pojawia się:

- potajemne picie, gdzie osoba potencjalnie uzależniona od alkoholu stara wypić większą ilość alkoholu w ukryciu, tak, aby nikt tego nie zauważył,

- ciągłe myślenie o alkoholu i zastanawianie się czy na spotkaniach towarzyskich znajdować się będzie w wystarczającą ilość alkoholu,

- łapczywość i chciwość: pierwsze kieliszki wypijane bardzo szybko, w małych odstępach czasu,

- poczucie winy i wyrzuty sumienia: osoba uzależniona zaczyna uświadamiać sobie swoje poczynania i odstępstwa od normy. Z tego powodu odcina się od wszelkich tematów związanych z alkoholem, odczuwa dyskomfort podczas rozmów z rodziną i bliskimi na temat potencjalnej choroby alkoholowej [5].

Taki stan rzeczy może utrzymywać się nawet przez kilka lat w zależności od stanu psychicznego i fizycznego osoby podejrzanej o alkoholizm.

Faza krytyczna (ostra) - w której występuje narkomania alkoholowa, czyli przymus fizyczny określany jako niepohamowany głód alkoholowy. Pijący nie potrafi już określić ilości spożywanego alkoholu. Jednoczenie potrafi zachować narzuconą sobie abstynencje. Alkoholik zaprzecza utracie kontroli nad nałogiem, wyszukuje coraz mniej racjonalne uzasadnienia dla picia. Pod wpływem zewnętrznej presji alkoholik narzuca sobie ostrą abstynencję, próbuje zmienić sposób picia, aby udowodnić sobie i najbliższym, że nadal jest w stanie kontrolować nałóg. Nacisk ze strony otoczenia wywiera u alkoholika poczucie winy i brak wiary we własne wartości, co musi kompensować sobie za pomocą alkoholu. W tej fazie zauważyć można poważne zaniedbywanie pracy i kontaktów z bliskimi osobami, utrata zainteresowania innymi aspektami życia, zmniejszenie się popędu seksualnego oraz konieczność ciągłego dostarczania alkoholu do organizmu.

Faza chroniczna (zejściowa) - pojawia się z okresami wielodniowej intoksykacji, Łzw. "ciągami picia". Alkoholik zaczyna pić z ludźmi 
ze znacznie niższych warstw społecznych, prawdopodobnie, aby poczuć się kimś lepszym $\mathrm{w}$ ich gronie. Zaczynają się problemy finansowe, co sprawia, ze alkoholik zaczyna eksperymentować z substancjami przyjmowanymi do organizmu (mogą to być perfumy, spirytus salicylowy lub alkohol niewiadomego pochodzenia). W momencie kiedy w organizmie zabraknie alkoholu nasilają się nieokreślone lęki, psychozy alkoholowe proste czynności zaczynają sprawiać coraz większe trudności, występuje wyraźne obniżenie sprawności motorycznej. Słabnie możliwość racjonalnego myślenia. W konsekwencji długich ciągów alkoholowych, a konfrontacją z rzeczywistością alkoholik czuje się pokonany przez nałóg. Wówczas taki stan może prowadzić do spontanicznych próby poddania się specjalistycznemu leczeniu odwykowemu lub wprost przeciwnie powoduje obsesyjne picie, ponieważ nie widzi już innego rozwiązania $[2,4,5]$.

\section{Wyniki}

Zjawisko uzależnienia od alkoholu występuje coraz częściej i niesie ze sobą bardzo przykre w skutkach konsekwencje.

1. Nowoczesny wzorzec postępowania pielęgniarstwa psychiatrycznego to podmiotowe traktowanie chorego, zachęcanie do udziału w procesie leczenia oraz aktywizowanie rodziny do udziału w terapii.

2. Rolą pielęgniarki psychiatrycznej jest: określenie potrzeb zdrowotnych, zgłębienie problemów pielęgnacyjnych, opieka nad pacjentem, wykonanie zleceń lekarskich, poradnictwo, psychoedukacja, psychoterapia, aktywizacja chorych z elementami terapii zajęciowej, rehabilitacja, edukacja zdrowotna.

3. Kluczową sprawą w opiece nad pacjentem z ZZA jest właściwa komunikacja terapeutyczna, ukazanie autentyczności, otwartości, życzliwości oraz zrozumienia. Traktując pacjenta indywidualnie zdobywamy jego zaufanie. Prowadzona wnikliwa obserwacja 
zachowań chorego, kontrola parametrów życiowych, ocena stanu fizycznego, udział $\mathrm{w}$ procesie leczenia oraz edukacja pacjenta są priorytetami w osiągnięciu pozytywnego efektu terapeutycznego.

\section{Bibliografia/Biblography:}

1. Państwowa Agencja Rozwiązywania Problemów Alkoholowych, http://www.parpa.pl/index.php/szkody-zdrowotne-iuzaleznienie/uzaleznienie, 19.04.2018.

2. Cierpiałkowska L., Ziarko M.: Psychologia uzależnieńalkoholizm.Wydawnictwo Akademickie i Profesjonalne. Warszawa 2010.

3. Górna K.: Pielęgniarstwo psychiatryczne. Podręcznik dla studiów medycznych. Wydawnictwo Lekarskie PZWL. Warszawa 2012,27-28.

4. Cierpiałkowska L.: Alkoholizm: przyczyny, leczenie, profilaktyka. Wyd. naukowe UAM, Poznań, 2000.

5. Frąckowiak M, Motyka M.: Problemy Hig Epidemiol. Zespół zależności alkoholowej. 2015,96 (2).

Otrzymano: 15.02.2019r.

Zaakceptowano: 22.03.2019r. 